\title{
SENTENCE-COGNITION IN NYĀYA EPISTEMOLOGY
}

\author{
1.
}

According to the Naiyāyikas, the logicians of the Nyāya school of Indian philosophy, there are four kinds of valid cognition, i.e. sense-perception (pratyakșa), inference (anumāna), comparison (upamāna) and verbal cognition (sábda-jn̄āna). Linguistic ut terances (sabda) are the means of verbal cognition, and only valid linguistic utterances can lead to valid verbal cognitions. For this reason, assessment of validity of linguistic utterances has become an essential part of most of the Indian philosophical systems. The concept of validity as it pertains to linguistic utterances, or rather to sentences, is a complex concept and it involves different kinds of problems. The validity of a linguistic utterance may be viewed from the point of view of the linguistic structure of that utterance as well as from the point of view of the truth value of the cognition generated by that utterance. In this paper, I have dealt with some aspects of this question. The first part of this paper deals with some general questions, while the second part deals specifically with certain arguments of Jagad iśa Bhaț̣ācārya, a medieval logician of great repute. These arguments are offered to establish that knowledge derived from linguistic utterances is a type of knowledge distinct from sense-perception, inference and comparison.

The notion of verbal cognition is more closely related to the notion of sentencemeaning than to the meaning of isolated lexical or morphemic items. ${ }^{1}$ Therefore, we shall briefly survey different conceptions of 'sentence' offered by Indian philosophical systems, and then turn to the critical examination of the Nyāya conception.

2.

The Sanskrit grammarians offer the following definitions:

(A)

$$
\text { eka-tïn vākyam. }{ }^{2}
$$

The literal translation of this definition runs as: "A sentence is a single inflected verb-form". The extended definition means: "A sentence is a group of words which has a single inflected verb-form (as its center)". A further extension of this definition is: (eka-tin-mukhya-visesyakam vākyam): "A sentence is a group of words which (centers around) only one principal verb-form". ${ }^{3}$

(B) $\quad \bar{a} k h y \bar{a} t a \dot{m}$ sāvyaya-kāraka-viseșanaìn vākyam. ${ }^{4}$ 
Literal translation: "A sentence is a group of words which contains a verb-form along with (related) action-promoters (kärakas, agent, object etc.), indeclinables and qualifiers".

(C) äkhyātà̇ saviśeșanà̇ vākyam. ${ }^{5}$

Translation: "A sentence is a group of words which contains a verb-form along with its qualifiers". This definition presents a simplified logical structure of a sentence as a group of words wherein the verb is the focus and all other words in a sentence are viewed as somehow specifying, qualifying and particularizing the semantic content of the verb-form.

Bhart?̣hari has provided a number of other hypothetical definitions, ${ }^{6}$ but the final emphasis of Bhartrinari is on the concept of indivisibility of the sentence and its meaning. He says that both are indivisible in 'reality', and that all the analytical divisions and isolated forms in grammar are but functional fictions. ${ }^{7}$ For him, the cognition of sentence-meaning is an instantaneous flash, with no real internal structure. ${ }^{8}$ Other schools in Indian philosophy have not accepted this radical doctrine.

The system of Mīmāmsā defines a sentence as:

$$
\text { arthaikatvād ekam vākyam. }{ }^{9}
$$

"A sentence is a group of words, such that it signifies a single self-contained idea". A definition such as this focuses on the purpose of a sentence rather than on its structure. The Mìmāmsakas are mainly concerned with ritual injunctions in the Vedic texts, and like to interpret each injunction as laying down a particular aspect of the ritual. Thus their definition is not strictly a definition of a grammatical notion of a sentence.

3.

Let us now turn to the Nyāya conception of a sentence. Some peculiar aspects of this conception, particularly as it was developed by the later Naiyāyikas, must be clearly understood. A sequence such as rāmah ghatam nayati 'Rama carries a jar' is a vākya 'sentence' for these logicians, but the mere accusative form ghatam 'a jar' is also sometimes referred to as a sentence $(v \bar{a} k y a) .{ }^{10}$ We must analyse the Nyāy a conception of a sentence keeping in mind this peculiarity.

The Nyāya system defines sakti 'power' or signification function of a word as the desire of God or of a community that a certain word should signify a certain meaning. ${ }^{11} \mathrm{~A}$ pada 'word' is defined as a (minimal) sound sequence which possesses sakti 'significatory power', or signification function. ${ }^{12}$ This category includes all stems, roots and affixes, or to use a modern term, all morphemic elements, without regard to the morpheme-allomorph distinction. This is the notion of the neologicians like Jagadiša. 
The early Nyāya exhibits a different conception. The Nyāya-sūtra of Gotama and the Nyāya-bhāsya of Vātsyāyana define a pada as a word that ends in either a finite verb inflection or a case-ending. ${ }^{13}$ This conception is identical with Pänini's definitions. ${ }^{14}$ The later Nyāya definition of pada shifts from an inflected word to a morphemic item.

4.

With this definition of a pada 'word' as a morphemic item, the later logicians define a $v \bar{a} k y a$ 'sentence' as follows: ${ }^{15}$

A sentence is a group of words, such that these words fulfil the conditions of a) mutual expectancy (äkänkșä), b) semantic or empirical compatibility (yogyatä), and c) contiguity (sannidhi).

Before discussing any details of this definition, it must be pointed out that the Nyāya system is actually dealing with propositional expressions or, to be more precise, expressions communicating qualificative cognitions (višișta-jñäna). A qualificative cognition has the content-structure of the type $x Q y$, ' $x$, qualified by $y$ '. Here $x$ is the qualificand (visesya), and $y$ is the qualifier (visesana, prakāra). If there are two morphemic elements, say $P_{1}$ and $P_{2}$, such that the meaning of the sequence $P_{1} P_{2}$ is: 'meaning of $P_{1}$, qualified by the meaning of $P_{2}$,' then the sequence $P_{1} P_{2}$ may be called a $v \bar{a} k y a$ 'sentence' or a propositional expression. Dominance of a certain meaning-item is determined by many different factors. ${ }^{16}$

For instance, the accusative singular form ghatam, which is a full propositional expression according to the neo-logicians, can be analysed as follows:

(1) ghațam

(2) ghata + am

(3) $\quad$ ghata- $=$ 'jar', $-a m=$ accusative sing. = 'object-ness'.

Let us disregard meanings such as 'singularity' for the moment. The meaning of the sequence ghatam, according to the neo-logicians, has the following structure:

'Objectness, qualified by a jar' = ghata-nirūpita-karmatva.

The sequence ghatam fulfills all the conditions in the definition of a sentence. The two morphemic items have mutual expectancy, semantic compatibility and contiguity. Therefore, the sequence ghatam is regarded to be a $v \bar{a} k y a$ 'sentence'.

Smaller propositional expressions can be combined with each other to build larger complex propositional expressions. This fits the atomistic metaphysics of this school. From ghatam 'a jar, the object' and nayati ' $x$ carries', we can build the larger sentence: ghatam nayati '(he) carries the jar'. The structure of the meaningcognition also gets more and more complex. For instance, instead of having a simple structure like $x Q y$, ' $x$, qualified by $y$ ', we find complex structures such as: $x Q(y Q z)$. 
The semantic paraphrase of a sentence such as:

John brings a jar.

can be written as:

agenthood $Q$ (John $Q$ (bringing $Q$ (objecthood $Q$ jar $)))=x Q(y Q(z Q(a Q b)))$

This is still a simplified version, and we have to include qualifiers such as 'singularity', 'present tense' etc. However, the example illustrates the Nyāya conception of the structure of sentence-meaning. The Nyāya conception covers sentences in the conventional sense of the term 'sentence', as well as many other sequences expressing propositional qualificative cognitions.

5.

With the above clarification concerning the Nyāya concept of $v \bar{a} k y a$ 'sentence', we can closely study some of the other conditions laid down in that definition. The first condition is that the components of a 'sentence' must have mutual expectancy ( $\bar{a} k \bar{a} \dot{n} k s+\bar{a})$. Annambhatța defines mutual expectancy in the following words: ${ }^{17}$

If a linguistic item $x$ cannot generate an integrated meaning-cognition due to the absence of a linguistic item $y$, then $x$ is said to have mutual expectancy with respect to $y$.

This defines interdependence of two linguistic elements. It is not clear, however, whether this mutual expectancy is exclusively semantic, syntactic or structural. For instance, the accusative singular ghatam 'a jar, the object' has expectancy for a verb like nayati 'he carries', and the stem ghata-has expectancy for the affix am. But the stem ghat a- has no expectancy for the word karmatva 'objecthood' which expresses the meaning of the accusative affix -am.

6.

There are some interesting discussions in the Nyāya texts on the concept of mutual expectancy. Quoting a view of kecit 'some logicians', Rājacūḍāmanimakhin says: ${ }^{18}$

Mutual expectancy is certainly a particular kind of co-occurrence of words ending in particular terminal affixes.

Speaking of the mutual expectancy of the two components, i.e. nila 'blue' and ghața 'jar', in the compound word nila-ghata 'a blue jar', Gadādhara says that this mutual expectancy could be described in structural terms. He says: ${ }^{19}$

(1) The word nila immediately precedes the word ghata. or

(2) The word ghața immediately follows the word nilla. 
If in a given compound $x y$, the elements $x$ and $y$ occur in the specific order $x y$, then the mutual expectancy could be structurally explained in terms of their fixed order. Similar structural expectancy may be observed in the stem-affix sequences, where the order is fixed.

It is possible to speak of a definite word order in the case of compounds or stem-affix sequences, but how could one speak of mutual expectancy as a fixed word-order in the case of Sanskrit sentences? The order of words may not be fixed, and yet Jagad ǐsa says: ${ }^{20}$

(In the case of the sentence gaur asti 'there is a bull'), the mutual expectancy turns out to be a particular order of words which is conducive to bringing out the relation of the meaningelement 'existence' to the meaning-element 'bull'.

Thus the Nyāya system seems to interpret mutual expectancy more in structural terms than in semantic or syntactic terms. It may be described as a particular kind of co-occurrence of words.

7.

Sanskrit grammarians have dealt with the concept of mutual expectancy in a more significant manner. Patañjali discusses the concept of vyapekṣ̄ 'meaning-interdependence' at some length. As S. D. Joshi points out, meaning-interdependence implies that two or more word-meanings require each other. ${ }^{21}$ Patañjali says: ${ }^{22}$

What do you mean by requirement between two words?

We do not say: "between two words".

What then?

Between two meanings.

Nāgeśa explains that mutual expectancy is actually a subjective factor, rather than a property of words or meanings. It is in fact the desire or the expectation of the listener for the cognition of meanings which need to complement the meaning of a given item. ${ }^{23}$ It is of the form of the question: "what is the meaning which is related to this meaning?" It is subjective and lies in the cognitive process of the listener. Expectancy being a cognitive factor cannot be a property of words or meanings. However, since this expectancy is with regard to meanings, it is superimposed on those meanings. Thus in a metaphorical sense we can speak of meanings being inter-expectant. But this cognitive expectancy, according to Năgeśa, can never be imposed on words. As he puts it, the cognitive expectancy arises only after one cognizes the meanings of the individual words. The stages of cognizing sentence-meaning are as follows: 


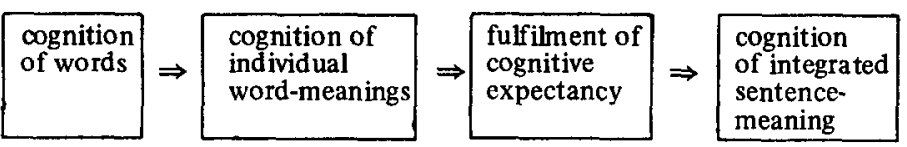

The conception of the Sanskrit grammarians is definitely a richer conception.

8.

There are some logical problems in the Nyāya definition of a sentence. Is it required that each member of the sentential word-group should have mutual expectancy with regard to every other member, or is it enough to have mutual expectancy with some member or members of that group? Though the later logicians of this school certainly want to make the nominative-word the focus of their syntax, e.g. the agent in the active voice and the object in the passive voice, we do not find a clear resolution of this issue in the definition of a sentence itself.

Let us look at the following examples given by Patañjali. ${ }^{24}$

nadyăs tișthati kūle

of the river, he stands, on the bank

He stands on the bank of the river.

$$
\begin{aligned}
& \text { sâlīnām te odanam dadāmi } \\
& \text { of grains, to you, rice, I give } \\
& \text { Of grains I give you rice. }
\end{aligned}
$$

In the first example, the word nadyās 'of the river' is semantically related to the word küle 'on the bank', and not with tișthat i 'he stands'. Hence, there is no mutual expectancy between nadyās and tișthati. Similarly, in the second example, there is no mutual expectancy between śălīnām 'of grains' and te 'to you', since sálīnām is connected with odanam 'rice' alone. That there is no semantic relation (sāmarthya) between the first two words in both the sequences is accepted by Kātyayyana and Patañjali, but they accept these sequences to be grammatically correct sentences. ${ }^{25}$

Thus we cannot say that every word in a sentence must be mutually expectant of every other word. Can we accept the other alternative, i.e. a member of sentential word-group must be mutually expectant with some other member of that wordgroup? This alternative is too vague. The grammarians' definitions of a sentence making the verb-form as the center and connecting every other word in the sentence directly or indirectly to that verb-form show a clearer perspective of semantic and syntactic relationships. While the Nyaya conception of mutual semantic linking is based on the concept of a qualificative cognition and appears to be rather linear, the grammarians'conception of semantic and syntactic linking appears to be like a wheel with the verb at its center and all other items linked to it from different directions. 
Nyāya

agent $Q$ (action $Q$ object)

object $Q$ (action $Q$ agent)

$x Q(y Q(a Q(b Q(c Q d))))$

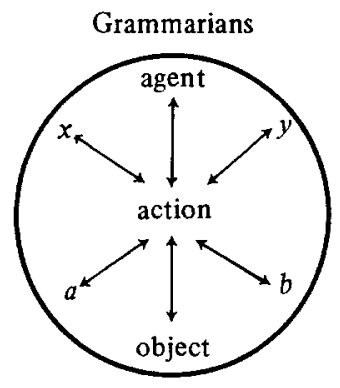

9.

The second important condition in the Nyāya definition of a sentence is that of yogyat $\bar{a}$ 'appropriateness' or 'semantic compatibility'. It is the mutual fitness of two or more word-meanings. The main concern of the school of Nyāya is not grammaticality of sentences. (In fact these logicians are quite famous for their contempt of grammar and grammarians.) Their main concern is validity or logical and empirical acceptability. Therefore, mutual compatibility of meaning-elements is an essential condition for a group of linguistic elements to constitute a logically and empirically acceptable propositional expression. The stock-example of lack of such mutual compatibility is as follows:

vahninā siñcati

He moistens (or sprinkles) with fire.

According to the Naiyāyikas, in the case of this sequence, there can be a cognition of the individual word-meanings, but there is no possibility of any valid integrated sentence-meaning. Mutually incompatible word-meanings cannot be integrated into an acceptable sentence-meaning. Hence the school of Nyāya does not consider this sequence to be a $v \bar{a} k y a$ 'sentence' ${ }^{26}$

10.

On the other hand, the Sanskrit grammarians do not accept semantic compatibility to be a necessary condition for a group of words to be regarded as a sentence. Nāgeśa refutes the view of the logicians that there can be no cognition of any sentence-meaning in the case of the sequence vahnina siñcat $i$ 'He moistens with fire'. ${ }^{27}$ According to the grammarians, word-meaning is of the nature of an intellectual mode or a notion, and external verifiability of the truth-value of a sentence is not a necessary condition for the apprehension of sentence-meaning. We must distinguish the stage of apprehending the sentence-meaning from the stage of evaluating its logical or empirical validity. A given sentence-meaning may be 
logically or empirically invalid, and yet there is nothing to stop that sentence from conveying its meaning. Even when there is no corresponding reality in the external world, a word can generate a meaning-cognition. For Sanskrit grammarians, the word vandhyā-suta 'son of a barren woman' is a perfectly meaningful word. Validity of a sentence consists in its lexical and structural soundness, and the Sanskrit grammarians will not care to consider the extra-linguistic truth-value.

11.

The difference between the two approaches outlined above is quite significant, and is firmly rooted in the fundamentally different professional aims of these two schools. The logicians aim at defining a word as a means of valid cognition, and hence their definition of a sentence must include only those sequences which lead to logically and empirically valid cognitions. Those words or groups of words which do not generate valid cognitions cannot be called 'sentences', once the term 'sentence' is directly linked with means of valid cognition. I think that this position of the logicians is quite valid. However, they almost fall in their own trap and argue that one cannot even comprehend sentence-meaning if the word-meanings are mutually incompatible. This is indefensible, and the grammarians are quite right in rejecting this position. On the other hand, the Sanskrit grammarians are exclusively committed to the formal aspects of a sentence. They claim that uitimately it is vivakșa 'speaker's desire' that prompts a speaker to use a particular group of words to express a particular meaning, and the science of grammar can judge only the formal features of linguistic utterances. The substantive and logical aspects are thought to lie outside the scope of grammar. Therefore, the grammarians' concept of acceptability is dependent solely on the formal properties of a sentence. With this background, let us look at the famous Chomskian examples: ${ }^{28}$

(A) Colorless green ideas sleep furiously.

(B) Furiously sleep ideas green color.

For the Naiyāyikas, both of these examples would be non-sentential, since neither of them leads to a valid cognition. But for the Sanskrit grammarians, the first sentence would be a grammatically acceptable sentence, but the second would be grammatically unacceptable, since it violates the formal rules of linguistic structure. ${ }^{29}$ However, the Sanskrit grammarians would perhaps most certainly agree that no person in his right mind would actually ever use the 'grammatically acceptable' sentence: 'Colorless green ideas sleep furiously'. 
12.

Before moving to the specific arguments of Jagadīsa Bhațtāāārya,we must briefly refer to the well known Nyāya theory of sentence-meaning: abhihitānvayavāda. This theory says that the constituent words of a sentence first express only their individual lexical meanings, and then these meanings of words are combined to produce the sentence-meaning. The interrelations of word-meanings which form a part of the sentence-meaning are not conveyed by the words themselves, but they are conveyed by the so-called relational seam (samsarga-maryād $\bar{a}$ ). ${ }^{30}$ This is a significant concept. Individual words in a sentence are said to denote the same meaning as is denoted by words in isolation. However, the sentence-meaning is not identical with the sum-total of the word-meanings. In the sentence-meaning, the individual word-meanings always appear in an integrated form. As a rule, according to the Naiyāyikas, that part of meaning which is not cognized from the words, but appears in the sentence-meaning, is said to be cognized from the juxtaposition of the words. ${ }^{31}$

Gadādhara explains that the juxtaposition of words in a sentence is quite significant, in that this is a major factor giving us the interrelations between different lexical and syntactic meanings. ${ }^{32}$ This interrelation between different word-meanings is promoted by the mutual expectancy between different words. ${ }^{33}$ Certain later logicians almost identify mutual expectancy with the particular juxtaposition of words in a sentence. ${ }^{34}$ The value of juxtaposition of words in communicating supralexical meanings has been explained recently by Gertrude Wyatt in a similar manner: ${ }^{35}$

Sapir has proved that in all known languages, juxtaposition is the simplest, most economical method of binding words together and of bringing them into some relation to each other, without attempting an inherent modification of these words. The very process of.juxtaposing concept to concept, symbol to symbol, forces some kind of relational feeling, if nothing else, upon us. Words and elements when they are listed in a certain order, tend not only to establish some kind of relation among themselves, but are attracted to each other in greater or in less degree.

No Naiyāyika could have expressed his own conception in more convincing terms.

\section{DISTINCTIVE EPISTEMOLOGY OF VERBAL COGNITION}

13.

According to the school of Navya-Nyāya, sentential meaning-cognition has to be differentiated from other modes of valid cognition. The obvious question is why can it not be included in any of the other modes of valid cognition, notably in sense-perception and inference. This is the question that has been discussed by Jagadîsa at some length.

The first alternative considered here is that of mānasa-pratyakṣa 'mental 
perception'. Can verbal cognition be included in mental perception? What is mental perception? The school of Navya-Nyāya considers mental perception to be a kind of sense-perception (pratyakșa). In every instance of sense-perception, there must be a connection (sannikarsa) between the object and the sense-organ. In sense-perception, a sense-organ presents information about an object to the mind, and the information is acquired through its connection with the outside object. However, in mental perception, there is no connection between the object and the sense-organ. Information about an object is presented to the mind through some previous cognition, such as memory, and the object is said to have been mentally perceived. In such a case that previous cognition itself is regarded to be a perceptive connection. The Nyāyakośa says: ${ }^{36}$

\begin{abstract}
Mental perception is that perception which is caused by both, normal and abnormal perceptive connections. For instance, the visual perception 'the sandalwood is fragrant' is a mental perception. Concerning the element of fragrance, there is an abnormal perceptive connection. But concerning the element of sandal-wood, there is the normal visual perceptive connection. The mental perception is produced by both of these perceptive connections.
\end{abstract}

The perceiver has a previous cognition of the fragrance of the sandal-wood, and at a later time, when there is a visual perception of sandal-wood again, the element of fragrance is brought to the mind through remembrance, and it somehow seems to become a part of the present cognition of sandal-wood. Here that remembrance, or the previous cognition itself is said to serve as a perceptive connection for the present cognition. Such a perceptive connection is called cognitive perceptive connection (jñäna-lakșana-prattyāsatti $=$ upanaya).

14.

If one considers the verbal cognition or the cognition of sentence-meaning to be a mental perception as outlined above, what would be the cognitive perceptive connection? One may say that the cognition of the individual word-meanings is the cognitive perceptive connection that leads to the mental perception of sentencemeaning. If that were the case, then, argues the neo-logician, it would be useless to state other conditions such as mutual expectancy in the definition of a sentence. He argues that if the cognition of sentence-meaning is a mental perception, then the individual word-meanings alone should be sufficient to produce this mental perception. The only necessary condition for a mental perception is the existence of a previous cognition which serves as a cognitive perceptive connection. Hence other conditions would have to be ruled out as being superfluous.

However, every school of Indian philosophy accepts these basic conditions of mutual expectancy etc., and therefore the characterization of the cognition of sentence-meaning as a mental perception cannot be accepted. 
Similarly, one cannot include the cognition of sentence-meaning into the process of inference. Every inferential cognition is based on a previous cognition of the relation of concommitance between the probans and the probandum. Hence, a group of words by themselves cannot explain the cognition of the sentence-meaning as an inferential process. One would have to presuppose a previous cognition of concommitance of some kind. According to the neo-logicians, there is no cognition of concommitance of any kind preceeding the cognition of sentence-meaning.

15.

Jagad issa Bhatțācārya points out that the cognition of sentence-meaning is quite different from sense-perception, mental perception and inference. ${ }^{37} \mathrm{He}$ asserts that the interrelations between individual lexical and syntactic meanings appear in the sentence-meaning, and that its cognition is generated specifically by words with mutual expectancy, compatibility and contiguity. In a sequence such as gauh asti '(There) is a bull', there are two individual word-meanings, i.e. 'bull' and 'existence'. These meanings are conveyed by the words gauh and asti through their 'God-given' significatory powers (sakti). However, in the sentence-meaning, these two wordmeanings do not appear as just added together, but they appear as interrelated to each other. This is the qualifier-qualificand relation (viśeșana-viśesya-bhāva).

According to Jagadisa, the meaning-element 'bull' is the qualificand, and the meaningelement 'existence' is its qualifier. Thus the structure of the sentence-meaning is:

gaur ast $=$ There is a bull. $=$ 'Bull' $Q$ 'Existence'

The relation between 'bull' and 'existence' is a fixed relation in the sense that we cannot accept either

(A) 'Bull' + 'Existence', or

(B) 'Existence' $Q$ 'Bull'

as representing the sentence-meaning of the sequence gaur asti. Jagad iśa clearly states that the cognition of sentence-meaning is different from a 'mere presentation of word-meanings. ${ }^{38}$

16.

With this definite idea of the structure of sentence-meaning, the difference between sentence-meaning and mental perception or inference is made explicit.

In a mental perception, if there are two cognita presented to the mind, through some previous cognition serving as the cognitive perceptive connection, then those two cognita are perceived as only added together, without any particular relation 
between them being explicitly perceived. According to the neo-logicians, the structure of a mental perception of $x$ and $y$ cannot be other than ' $x+y$ '.One has no way of asserting either the relation $x Q y$, or $y Q x$.

If one would claim that the cognition of sentence-meaning is a mental perception, then the structure of that cognition must be something like 'bull' + 'existence'. With the cognition of a sentence-meaning included in mental perception, one cannot explain why its structure is 'bull' $Q$ 'existence'. Therefore, the cognition of sentencemeaning cannot be a mental perception.

17.

In the case of inferential cognition, the situation is exactly opposite. In every inferential cognition, there is invariably some relation between the cognita. The major term (sädhya) and the minor term (pakșa), or the middle term (hetu) and the minor term (pakșa) must have the qualifier-qualificand relation. But the important point, according to Jagadiśa, is that either of the cognita can become the qualificand, and the other becomes the qualifier. Thus, with the same major and minor terms, there can be two different inferential states, due to the difference caused by the inversion of the qualifier-qualificand relation. For example, the same situation of inference can result in:

(a) parvate vahnih $=$ '(There) is fire on the mountain.'

$$
=\text { 'Fire' } Q \text { 'Mountain' }
$$

and

(b) parvato vahnimān = 'The mountain is possessed of fire.'

$$
=\text { 'Mountain' } Q \text { 'Fire' }
$$

According to Jagadísa, both of these cognitive states are valid and acceptable.

Such is not the case with the cognition of sentence-meaning. In the cognized sentence-meaning, the relation between the word-meanings is a fixed relation, and no inversions are valid. An objector may argue that all cognitions should have the structure ' $x+y$ ', and hence the sentence-meaning should also have the same structure..$^{39}$ Jagadisa says that such a simplified structure cannot be accepted as representing all kinds of cognition. One has to accept the existence of qualificative cognition. The inferential cognition and the cognition of sentence-meaning are always qualificative cognitions. ${ }^{40}$

18.

Jagadiśa says that the view that sentence-meaning is always of the nature of a qualificative cognition, and can only be generated by words with mutual expectancy 
etc. is based on the analytical foundations of anvaya 'concurrent occurrence' and vyatireka 'concurrent non-occurrence'. ${ }^{41}$ If the members of a word-group do not have mutual expectancy etc., then in that case, one does not find the resulting sentence-meaning of a qualificative nature. On the other hand, wherever such qualificative sentence-meaning is found, one also finds that the words generating that qualificative sentence-meaning indeed have the properties of mutual expectancy etc. The method of anvaya-vyatireka is often used in the Nyāya texts in connection with the two types of concommitance used in inference. The anvayaconcommitance is of the form $P \supset Q$, while the vyatireka-concommitance is of the form $\sim Q \supset \sim P$. But here Jagadiśa uses the terms anvaya and vyatireka to refer to the patterns of observation, and in this context, anvaya 'concurrent occurrence' is of the form ' $P \supset Q$ ', and vyatireka 'concurrent non-occurrence' is of the form ' $P \supset \sim Q$ '. If $P$ stands for words with mutual expectancy etc. and $Q$ for the integrated sentence-meaning, we can substantiate the truth of ' $P \supset Q$ ' and ' $\sim P \supset \sim Q$ ' by observation of sentential and non-sentential word-groups.

19.

Can the cognition of sentence-meaning be viewed as an instance of memory? Memory (smrtit) of an object $x$ is preceded by a mental impression (samskāra) of $x$. This mental impression of $x$ is itself produced by a direct experience of $x .^{42}$ Thus the process of memory may be represented as:

\begin{tabular}{|c|c|c|c|c|c|c|}
\hline $\begin{array}{l}\text { Direct } \\
\text { Experience } \\
\text { of } x\end{array}$ & $\Rightarrow$ & $\begin{array}{l}\text { Mental } \\
\text { Impression } \\
\text { of } x\end{array}$ & $\Rightarrow$ & $\begin{array}{l}\text { Awakening } \\
\text { of the } \\
\text { Impression }\end{array}$ & $\Rightarrow$ & $\begin{array}{l}\text { Memory } \\
\text { of } \\
x\end{array}$ \\
\hline
\end{tabular}

Only a mental impression of $x$ can cause memory of $x$. A mental impression of $x$ cannot cause memory of $y$.

Jagadissa says that the cognition of sentence-meaning cannot be regarded as an instance of memory, since it is not always found to be preceded by mental impressions of identical form. ${ }^{43}$ This is an interesting argument. If a listener understands a given sentence $S$ at a given time, then this meaning-cognition would generate a mental impression of the meaning of $S$. This impression would help understand the sentence $S$ at a later occasion. However, this process cannot explain why the sentence $S$ was understood in the first instance. One cannot always say that he understands a given sentence, because he has previously understood the same sentence. This is not a satisfactory alternative.

20.

Jagadissa presents some further arguments to reject inclusion of the cognition of sentence-meaning under mental perception. ${ }^{44}$ In a mental perception, says Jagadiśa 
anything that is presented to the mind by a previous cognition can become a cognitum. That is not the case with the cognition of sentence-meaning. Only those meanings which are presented by words with mutual expectancy etc. and those which are provided by the relational seam become constituents of sentence-meaning. ${ }^{45}$ If one insists on considering the cognition of sentence-meaning to be a mental perception, then along with the meanings provided by words with mutual expectancy etc., other elements which are brought to the mind at that time through the awakening of any previous cognitions would also form part of the sentence-meaning. If such extraneous elements become constituents of a sentence-meaning, this is not desirable.

How can one prove that such extraneous elements indeed never become constituents of the sentence-meaning? Jagadissa takes recourse to the standard means of confirming the nature of any cognition. This is the 'reflective cognition' (anuvyavasäya). After a cognition of an object, sometimes there is a reflective cognition about the previous cognition of that object. After the cognition 'This is a jar', there can be a reflective cognition of the form: 'I know that this is a jar' or rather: 'I know that I know that this is a jar'. The reflective cognition with the structure ' $I$ know that $I$ know ...' is a means of judging the structure of the first cognition. Jagadiśa argues that the reflective cognitions of the cognition of sentence-meaning indicate clearly that elements not provided by words or the relational seam cannot become constituents of sentence-meaning. ${ }^{46}$

21.

An objector, as presented by Jagadissa, insists that the cognition of sentence-meaning is a mental perception, but he attempts to reformulate his position in such a way that he thinks he can avoid the problems mentioned above. What follows is the reformulated argument of the objector: ${ }^{47}$

The reflective cognition of the cognition of sentence-meaning, with the meanings $x, y$ and $z$, can be generated only by the cognition of sentence-meaning, with the meanings $x, y$ and $z$, and which is itself produced by the words which have their ('God-given') signification function to represent the meanings $x, y$ and $z$.

The implication of this strange reformulation is that if in a specific case, some meanings are cognized through the words of the sentence, and some others are brought to the mind through certain previous cognitions being awakened, then there would in fact be two distinct mental perceptions. One mental perception would be comprised of the meaning-elements signified by the words and provided by the relational seam. The other mental impression would consist of the extraneous elements brought to the mind. This is the reformulated theory of the cognition of sentence-meaning as a mental perception. 
This obviously involves undesirable prolixity. Under normal circumstances, a mental perception can include everything that is presented to the mind by whatever previous cognitions at a given moment. But the above formulation imposes restrictions on the mental perception of sentence-meaning. Thus the mental perception of sentence meaning does not remain a normal mental perception, but becomes a very special kind of it, such that the normal epistemic conditions of a mental perception do not apply to it. Then, asks Jagadiśa, why call it a mental perception? ${ }^{48}$

22.

There is a more serious objection to the above-mentioned reformulation. According to Jagadissa, the sentence-meaning does occasionally include some elements which are neither presented by the words nor by the relational seam. For example, the sentence ghatena jalam annaya 'Bring water in a jar' means something in addition to the meanings signified by the words or by the relational seam. Obviously one cannot bring water in a jar which is broken or which has holes in it. If the sentence has to correspond to the intention of the speaker, then from the class of jars, one must exclude those jars which have holes in them. Thus, according to Jagadis a, the sentence 'Bring water in a jar' itself comes to mean: 'Bring water in a jar without holes'. ${ }^{49}$ According to Jagadiśa's own judgement, the reflective cognition of the cognition of the meaning of this sentence confirms the inclusion of 'without holes' in the sentence-meaning. If one adheres to the previously stated reformulated view that the cognition of sentence-meaning is a mental perception, then one cannot explain how the meaning 'without holes' forms part of the sentence-meaning. It must be noted that there is no agreement among Indian philosophers on inclusion of such elements in the sentence-meaning.

23.

Jagad iśa rejects inclusion of the cognition of sentence-meaning into inference from a different point of view. In an inferential cognition, only that element (i.e. the major term) which is previously known as being invariably concommitant with the middle term occurring in the minor term can appear as the cognitum. ${ }^{50}$ If the cognition of sentence-meaning is included in the inferential process, then only those elements which are pre-cognized (pürva-parämrșta) in the above-mentioned way would become cognita of the sentential meaning-cognition. However, this is an unrealistic restriction and is contrary to one's experience. 
24.

One may prefer to think that the memory of the meaning-elements generated by words with mutual expectancy etc. is the cause of the cognition of sentencemeaning. In this veiw again there can be two alternatives. Though the cause of the resulting sentential cognition is supposed to be memory of the individual meaningelements, yet the finally resulting cognition of sentence-meaning may be supposed to be either a mental perception or an inferential cognition.

This formulation has been rejected by Jagad iśa, since in both the alternatives it creates difficulties. These difficulties have already been pointed out in the previous discussions. ${ }^{51}$

25.

The purpose of this paper has been to point out some of the aspects of the Nyāya conception of a vākya 'sentence', drawing attention to those epistemological arguments of Jagadīsa Bhațțācārya which have so far received little attention. Other arguments of Jagadisáa rejecting inclusion of verbal cognition into inference by Vaiśeșikas and Buddhists have been discussed at some length by S. C. Chatterjee. ${ }^{52}$ Though the particulars of the arguments of Jagad iśa may appear somewhat oldfashioned to a modern philosopher, the general direction of the arguments is quite stimulating. The issues raised by Jagadissa concerning the structure of the various modes of cognition and the structure of the linguistic cognition in particular are quite significant, and these models should prove to be of interest to modern students of the cognitive aspects of linguistic communication.

Dept of Linguistics, University of Michigan

Ann Arbor, Michigan

\section{NOTES}

1 The term śabda 'word, linguistic unit' is elastic enough to range from individual sounds to sentential sequences and from pronounced words to the communicative aspects of language. The term śäbda-bodha normally refers to sentential meaning-cognition and this cognition is represented by different schools of Indian philosophy with different technical paraphrases. These technical paraphrases are held as representing the structure of the meaning-cognition.

${ }_{2}$ eka-tin väkyam, Vărttika by Kätyāyana on $\mathrm{P}(a \bar{a} n i n i) ~ 2.1 .1$. For discussions on this värttika, see: Matilal (1966), pp. 377-8 and Joshi (1968), pp. 108 ff. also Devasthali (1974).

3 This is a traditional extension of the definition to include complex sentences with a main clause and other subordinate clauses.

4 Varttika on P.2.1.1. Also see: Joshi (1968), p. 105.

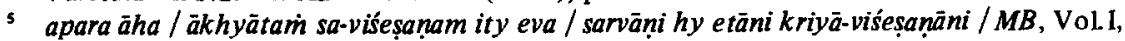
Sec. I, p. 337. (MB on P.2.1.1.) Also: Joshi (1968), p. 108 and Devasthali (1974). 
- Vākya-padìya II, 1-2.

7 Vākya-padīya II. 7: "Just as a partless single cognition of (a mosaic of) all (different parts) is analysed (consequently) in accordance with the difference in the perceived (parts), so is a cognition of sentence-meaning (only subsequently analysed)."

II. 8-9: "Just as a single homogeneous picture is described (subsequently) in terms of differentiating (features) such as the blue color which are of distinctive characteristics, similarly a sentence which is a single entity complete in all respects is subsequently described in terms of mutually expectant words which are ('in fact') different from (the indivisible sentence)." II. 10: "Just as in a given inflected word, the stem, the affix etc. are isolated (subsequently through linguistic analysis), similar is the analytical extraction of individual words in a given sentence."

II. 13: "The (sentential) linguistic unit has no ('real') division; then how can there be such divisions in the (sentence-) meaning? An ignorant person comes to comprehend different derivational processes through (these 'unreal') analy tical distinctions."

II. 38: "Grammarians say that the (descriptive) means are such that they have to be (provisionally) adopted and eventually given up (once the real nature of language is 'internalized'), and there is no inherent compulsion in adopting different (descriptive) devices."

- Väkya-padìya II. 22-29.

9 The complete statement of the definition is as follows: arthaikatvād ekam vākyam, sākäinkșam ced vibhäge syàd, Jaimini-sütra (2.1.46). This has also been stated by Bhartrhari in Vákyapadiya (II.3). So long as a single purpose is served by a number of words, they form a single sentence, but only if any one of these words, on being disjoined from the rest, becomes 'wanting'. Ganganath Jha has the following observations: "There is a difference among the Bhăttas themselves regarding the exact meaning of the term 'artha' in the compound 'arthaikatvät' in the sūtra. Pārthasārathi Mishra takes it in the sense of purpose, according to which all the words, phrases and clauses that serve a single purpose - of indicating details connected with an act for instance, - are to be treated as 'one sentence'. Someshvara Bhatta in the Nyäyasudhä, on the other hand, takes the word 'artha' in the sense of idea; so that any group of words that expresses one complete idea or judgement is to be treated as 'one sentence'. The difference in reality comes to this that while, by the former view, the definition of 'one sentence' is applicable to Vedic sentences only, - by the latter, it becomes applicable to all kinds of sentences, Vedic as well as secular.", Jha (1933), I, p. 215. Also see: Devasthali (1959), pp. $190 \mathrm{ff}$.

10 Jagadīśa says: na vā ghatah pacatity etayoh pratyekam na vākyam, SSP, p. 66. Translation: "It is not the case that the expressions ghatah and pacati are individually not sentences." Also see: Matilal (1966), p. 379.

"Ś Śktam padam / asmāt padād ayam artho boddhavya itīisvarecchā-samketah śaktih /, TS, p. 66; ädhunika-samketite tu na śaktir iti sampradāyah / navyās tu iśvarecchā na saktih kintv icchaiva / tenädhunika-samketite'pi saktir asty evety ähuh /, KM, p. 549. The older tradition believes that the semantic function of a word is God's desire that a certain word should express a certain thing, and therefore, words which are only recently introduced into the usage do not possess a 'legal' semantic function. The neo-logicians believe that semantic function of words is based on the desire of the community, so to say, and not on the desire of God.

12 śaktam padam, TS, p. 66; KM, p. 581; Matilal (1966), p. 379, says: “An 'atomic' pada, according to them, is the smallest meaning-bearing phoneme sequence. ... According to this theory, even an affix or suffix should be called a pada or word, provided one can assign some significance to it."

${ }^{13}$ te vibhakty-antāh padam, Nyāya-sūtra (2.2.58). The Nyāyabhäsya of Vātsyāyana says: varnāh vibhakty-antäh pada-samiñāh bhạvanti / vibhaktir dvayì nāmiky ākhyãtiki ca / 'brāhmanah' 'pacati' ity udāharanam / 'upasarga-nipātās tarhi na pada-samiñ̄āh / laksanāntaram vācyam' iti /

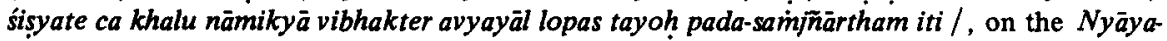
sütra (2.2.58). Translation: "The sound-sequences ending with terminal affixes are called padas. The terminal affixes are twofold: case-endings and verbal endings. The examples are brähmanah 
and pacati. (Objection:) If that is the case, then the indeclinables and prepositions cannot be called padas, and hence a new definition should be given. (Reply:) The deletion of case-endings after indeclinables is prescribed (by the grammarians) in order to obtain the designation pada

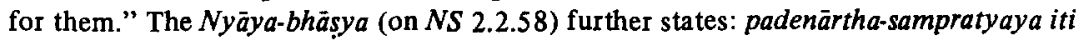
prayojanam, "The purpose (of giving the definition of pada 'an inflected word') is (to indicate) that meaning is signified by an inflected word (pada)." This is a very significant statement. In the history of the Nyāya system, the word pada has shifted from 'inflected word' to 'morphemic item'. Matilal (1966, p. 379) says that this is a shift from a 'formal' definition to a 'semantic' definition. This is quite justifiable. However, a comparison of the Nyāya-bhāssya statement quoted above with later tex ts indicates perhaps a shift within semantic assumptions. Vātsyāyana seems to say that only a pada 'an inflected item' is capable of signifying meaning, while in later times we find that even morphemic items are held as having a capacity of signifying meaning. This shift is quite interesting. Kätyāyana's vārttikas on P.1.2.45 indicate the same problem. On the one hand, Kātyāyana raises an objection to Pānini's characterization of a nominal stem as being meaningful. He says that a stem cannot be meaningful, since a stem alone is never used in the real usage (arthavattā nopapadyate, kevalenāvacanāt). Thus, from this communicative point of view, only inflected words can convey meaning. However, this objection is answered by saying that meaningfulness of stems and affixes is established through logical analysis of inflected words (siddham tv anvaya-vyatirekäbhyäm). Thus, stems and affixes do have 'abstracted' meanings. Here we are actually talking about two different levels of meaningfulness. The shift in the Nyaya system can, then, be explained as a shift from one semantic level to another semantic level. For a discussion of these concepts, see: Deshpande (1972), pp. $11 \mathrm{ff}$. 14 sup-tin-antam padam, P.1.4.14. For a detailed discussion of the Pāninian concepts, see Deshpande (1972), pp. 18-24.

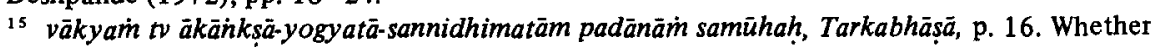
these three conditions should or should not be included in the definition of a 'sentence' has been a matter of controversy. Do they define a 'sentence' or a 'valid sentence' (pramānam väkyam)? Matilal $(1966, \mathrm{p} .382)$ touches upon this point. This is a semantic dispute. If we use the word 'sentence' in a loose sense, then these three conditions define a 'valid sentence', but if the word 'sentence' is strictly used in the sense of 'valid sentence', then these three conditions define a 'sentence'. While Annambhatta says that a sentence is a collection of words, and that a valid sentence is a collection of words which satisfies the three conditions; Keśavamiśra says that a group of words satisfying the three conditions is a sentence, and that a group of words which does not satisfy these conditions is no sentence at all. (TS, pp. 65 ff; Tarkabhäsã, p. 16). Instances of the loose usage of the word vākya 'sentence' are found even in Patanjali's Mahăbhășya (I, Sect. I, p. 105). Patañjali speaks of meaningful and meaningless sentences (loke hy arthavanti cānarthakāni ca vākyāni dr'śyante).

16 Systems differ on whether the meaning of the stem is dominant (prakrty-artha-prādhānya), or whether the affix-meaning is dominant (pratyayarrtha-prādhänya). If $x$ is affix-meaning and $y$ is stem-meaning, then according to the first view, the meaning structure is $y Q x$, while according to the second view, it is $x Q y$. The Neo-logicians believe that the stem-meaning is dominant.

${ }_{17}$ padasya padāntara-vyatireka-prayuktānvayānanu-bhāvakatvam ākänkssāa, TS, p. 67. For details on the dispute whether mutual expectancy helps sentential meaning-cognition simply by its existence or only if it is known prior to the meaning-cognition, see: Matilal (1966), p. 383. 18 kecit tu-vibhakti-viśsesavat-pada-samabhivyāhāara evākānnkșä, Mani-darpana, p. 15.

19 samāsa-sthale ca ghațādi-padāvyavahita-pūrva-varti-nülādi-padatvam, nìlàdi-padāvyavahitottaravarti-ghatădi-padatvaín vāa ākāinkșă, Vyutpatti-vāda, p. 34. Gadādhara who considers a particular ordered sequence of elements to be representing the structural mutual expectancy in a compound is aware that in an inflected language like Sanskrit the ordered sequence of words is not necessary in a sentence. The order is quite flexible. Thus he talks only of samabhivyahära 'co-occurrence' of words as representing the mutual expectancy in the case of uncompounded usages like nilo 
ghatah 'a blue jar'. See: Vyutpattivāda, pp. 33-34: prathamā-vibhakty-anta-ghatädi-pada-samabhivyährta-prathamänta-nīlädi-padatvam eva asamasta-nīla-ghata-padādy-äkänksạa, "The mutual expectancy in the case of uncompounded sequences such as nilah ghatah 'a blue jar' can be explained as the property of having the word ghata with a nominative ending co-occur with the word nila with a nominative ending."

${ }^{20}$ gavādāv astitvāder anvaya-bodhänukūlänupūrvì-paryavasitā tv ākāinkṣâ, SSP, p. 3.

21 S. D. Joshi (1968), p. 87, fn. 144.

${ }^{22} k \bar{a}$ punah śabdayor vyapekșä ? na brümah śabdayor iti / kim tarhi ? arthayor iti /, MB, I,

Sect. II, p. 332 (MB on P.2.1.1). Kunjunni Raja (1963, p. 155, fn. 3) observes: "Strictly speaking sāmarthya is the capacity of the words for mutual association, vyapeksā is their interdependence, and $\bar{a} k \bar{a} \dot{n} k s \underline{a}$ is the need one has for the other for completing the sense." In a way vyapekșa and $\bar{a} k \bar{a} \bar{n} k s \bar{a}$ represent different aspects of the same phenomenon.

${ }^{23} P L M$, pp. $77 \mathrm{ff}$.

${ }^{24} M B$ (on P.2.1.1), I, Sect. II, p. 338: yukta-yukte nadyäs tișthati küle / vrkșasya lambate

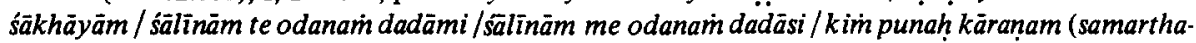
nighāto) na sidhyati? asamarthatvāt /, "Examples for indirectly connected words: nadyäs tișthati $k \bar{u} l e$ : '(He) stands on the bank of the river'; vrkssasya lambate säkhayām: '(It) hangs on the branch of the tree'; sálìnām te odanam dadāmi: 'Of grains I give you rice'; śălinām me odanam dadāsi: 'Of grains you give me rice'. What is the reason that (the rule for loss of accent, i.e. P.8.1.28, etc. conditioned by the semantic relation of the two consecutive words) does not apply in these examples (for the initial words of each sentence)? Because (the words involved) are not semantically connected." The last two examples are not for the loss of accent but for the forms te and me for the regular tubhyam and mahyam. P.8.1.28 says that a verb preceded by a non-verb loses its accent. If this rule is conditioned by the semantic relationship of the verb and the non-verb, then the rule will not apply to the first two examples. Similarly, tubhyam and mahyam can be substituted by $t e$ and $m e$, if preceded by another word. Here, if the same condition applies, the rule will not apply to the last two examples.

${ }^{25}$ Kāty ayyana suggests that the problems pointed out in the fn. 24 can be remedied by not having the condition 'semantically related words', but by having the condition restated as: 'within the same sentence'. With this restated condition, the loss of accent does apply to the verb tișthati in nadyàs tișthati küle 'he stands on the bank of the river', despite the fact that $n a d y \bar{a} s$ and tișthati are not semantically related. They, however, occur in the same sentence (väkya). See: vārttika: samāna-väkye nighäta-yușmad-asmad-ādeśā vaktavyāh, on P.2.1.1. ${ }_{26}$ eka-padārthe'para-padārtha-sambandho yogyatä / taj-jñānābhāvāc ca vahninā siñcatīty-ädau na śäbda-bodhah, KM, p. 632; arthābādho yogyatā, TS, p. 67. Viśvanātha and Annambhaț̣a emphasize the positive and the negative aspects of yogyata. Yogyatã indicates that two wordmeanings, or rather referents, must be compatible with each other, so that they can be naturally related to each other.

${ }^{27}$ ata eva vahninā siñcatīti vākyam ayogyam / vahneh sekānvaya-prayojaka-drava-dravyatvābhāvāt / etādrśa-sthaleșu nānvaya-bodhah kin tu pratyekam padārtha-mätram iti naiyāyikāh / tan na / bauddhārthasyaiva sarvatra buddhi-visayatvena bādhasyāsambhavāt / harir apy āha'atyantā-saty api hy arthe jñānam sabdah karoti ca' iti / ato vandhy $\bar{a}$-sutādi-śabdānām prātipadikatvam /,PLM, pp. 81-82. It is important to note that while the Naiyāyikas consider word-meaning to be the referred thing, or the referred items from their realistic ontology, Nägeśa argues that words immediately correspond to conceptual structures which may or may not directly correspond to structures in one's ontology. Thus Nãgeśa insists on distinguishing two levels of artha 'meaning', i.e. conceptual or notional and on tological. What is directly relevant to the process of linguistic communication is the conceptual structure of semantic ontology, than the structure of 'external' ontology. Nāgeśa presents some very interesting arguments in his Laghumañjūsa (pp. 203 ff.). If the word ghata 'jar' were to convey external reality of a jar, then a sentence such as ghatah asti 'there is a jar' must involve a redundant verb. A sentence such as 'a jar does not ex ist' would almost be impossible, because non-existence 
conveyed by the negative verb would necessarily contradict the inherent existence conveyed by the word 'jar'. In Nāgeśa's view, the verbs 'exists' and 'does not exist' in the sentences 'a jar exists' and 'a jar does not exist' are used to convey external existence and non-existence of the jar which always has a conceptual existence conveyed by the word 'jar'. Thus, for Nāgeśa, neither the words 'a horn of a rabit' nor the sentence 'a horn of a rabit does not exist' are meaningless. For him, the sentence 'a horn of a rabit does not exist' means that the horn of a rabbit which does have a conceptual existence does not have any external existence. Nägeśa's view is a middle path between the extreme idealism of the Buddhist logicians for whom words correspond only to conceptual structures and there are no "real" ontological structures, and the ex treme realism of the Vaiśesikas for whom words directly stand for the outside objects.

28 Noam Chomsky (1964), p. 385, fn. 5.

29 It is important to note how the scope of 'grammar' has shifted. While the Sanskrit grammarians would consider the sentence 'an apple eats John' to be grammatically acceptable, though empirically unacceptable, modern linguistic theories try to extend the notion of 'grammar' in such a way that an 'ideal grammar' will not generate such sentences. In ancient India, these two different aspects of the sentence 'an apple eats John' would be handled by two different departments. While grammarians would limit themselves to the validity of the structure, logicians would take responsibility of judging the logical and empirical validity.

${ }^{30}$ The word samsarga stands for 'relation, connection, contact', and maryādā means 'boundary'. Thus, samsarga-maryā $\bar{d} \bar{a}$ refers to the point of contact or a relational seam between the two words. It is something like a feeling of inter-relatedness created by the juxtaposition of words. ${ }^{31}$ padād anupasthitasya samsargataya bhänam iti niyamah, $P D$, p. 28.

${ }^{32}$ śäbda-bodhe caikapadārthe'para-padārthasya samsargah samsarga-maryādayā bhäsate, Vyutpattivāda, p. 1.

${ }^{33}$ äkänikșa-prayojya-samsargatvam, Prakāsa on Vyutpatti-vāda, p. 2.

${ }^{34}$ śäbda-bodhe eka-padārthānuyogikāpara-padārtha-pratiyogika-saminsarga-bhāsikā samabhìvyāhära-rūpā ākänksṣā eva, Jayā on Vyutpatti-vāda, p. 2.

${ }^{35}$ Quoted by $\mathrm{O}$. Hobart Mowrer in 'The Psychologist Looks At Language', Readings in the Psychology of Language, ed. by L. A. Jakobovits and Miron, Prentice-Hall, New Jersey, 1967, p. 13, fn. 17.

${ }^{36}$ upanita-bhānam-laukikālaukikobhaya-sannikarșa-janyam j̄̄nānam / yathā surabhi candanam ity-ädau pratyakșam upanita-bhānam bhavati / tac ca saurabhyāmśe alaukika-sannikarșah, candanāmiśe laukika-sannikarsaś caitad ubhābhyäm janyata iti bodhyam, NK, p. 163.

${ }^{37}$ SSP, pp. 6-7.

${ }^{38}$ na tu padārthānām upasthiti-mātram, SSP, p. 7.

${ }^{39}$ na tu padōrthānām upasthiti-mätram, viśișta-mater änubhavikatvād, anyathānumiter apy apaläpāpatteh, SSP, pp. 7-8.

40 Ibid.

41 For details, see: Cardona (1967-68), and Deshpande (1972), pp. 11-17 ('Logical Basis of Semantic Analysis').

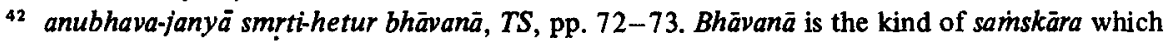
is involved in the production of smrti 'memory'. A more technical formulation of the relationship between anubhava 'direct experience', samskāra 'mental impression' and smrti 'memory' is given by the commentary Nilakantha-prakāsikā: tat-tad-visayaka-smrtim prati tat-tad-visayakasamskâra mi prati ca tat-tad-visayakiannubhavatvenaiva hetută, TS, p. 381. This very concept is expressed by Jagadīśa by his expression samānākāra-saminskära, SSP, p. 8.

${ }^{43}$ na cäsau smṛtih̆, samānākāra-saminskāräprabhavatvāt, SSP, p. 8.

44 Ibid.

45 nāpi sākșāt-kärah, sākānksạa-padenaiva prakārāntareṇāpy upasthitārthasya upanaya-maryādayāvagāhitāpatteh, SSP, p. 8.

46 na ceștāpattir anubhava-virodhät, tad-uttaram tathävidhānuvyavasāyäpatteś ca, SSP, p. 8.

J. N. Mohanty (1966), p. 91, uses the symbol $K_{2}$ to stand for the anuvyavasāya of $K_{1}$, if $K_{2}$ is 
the knowledge which apprehends $K_{1}$, where $K_{1}$ is a direct cognition. He renders the term anuvyavasäya by 'introspective awareness'.

47 tat-tad-artha-visayaka-śäbda-mater anuvyavasāyam prati tat-tad-artha-sākānkșa-pada-janyatad-gocara-śäbdatvena vișaya-vidhayā hetutva-kalpanāyām ati-gauravāt, SSP, p. 8.

48 Ibid.

49 itara-bädha-labdhasya chidretaratvāder apadārthasyāpi avagähitvena sábda-mater anuvyavasiyamānatvāt, SSP, p. 8. This whole argument fits in the tradition of the old school of Nyāya, which accepts tâtparya 'speaker's intention' as one of the important aids in understanding the sentence-meaning. The Kärikävalì holds the same view. Perhaps, Jagadiśa was not sure of its validity himself, and hence gave additional arguments. The two commentaries on the SSP, Krșnakānti and Rämabhadri refer to this view as belonging to the old school and doubt its validity $(S S P$, p. 9.).

so $S S P$, p. 9.

51 SSP, pp. 9-10.

s2 S. C. Chatterjee (1939), pp. 349 ff.

\section{BIBLIOGRAPHY AND ABBREVIATIONS}

Primary Sources

KM Kārikāyalī by Viśvanātha Tarkapañ cānana with the auto-commentary Muktāvalī, with other commentaries, Sri Balamanorama Series 6, Madras, 1923.

LM Vaiyākarana-Siddhānta-Laghu-Mañjūsā by Nāgeśa Bhatța, Kāśĩ Sanskrit Series 163, Banaras, 1963.

Manidarpana by Rājacūḍämaṇimakhin, Śabda-pariccheda, Trivandrum Sanskrit Series XXXIV, Trivandrum, 1913.

MB Mahābhāssya by Patañjali, with the commentaries by Kaiyața and Năgeśbhațtạ, in three vols., Motilal Banarsidass, Delhi, 1967.

NK Nyāyakośa by Bhimacarya Jhalkikar, revised and re-edited by Vasudeva Sastri Abhyankar, Bhandarkar Oriental Research Institute, 3rd edn., Poona, 1928.

Nyāya-bhāsya by Vātsyāyana, Poona Oriental Series 58, Poona, 1939,

PD Parișkäradarpana by Venimadhava Shukla, Haridas Sanskrit Series 35, Banares, 1934.

PLM Parama-Laghu-Mañjūṣā by Nāgeśabhaț̣ta, M.S. University'of Baroda Research Series 7, Baroda 1961.

SSP Śabda-Sakti-Prakāśikā by Jagadīśa Bhațtāāārya, with two commentaries, Kāśí Sanskrit Series 109, Banaras, 2nd edn., 1973.

Tarkabhāṣā by Keśavamiśra, Oriental Book Agency, Poona, 1953.

TS Tarka-Sangraha by Aṇnambhațta, with nine commentaries, Käśĩ Sanskrit Series 187, Banaras, 1969.

Vãkya-Padīya by Bhartrhari, ed. by K. V. Abhyankar and V. P. Limaye, University of Poona Sanskrit and Prakrit Series 2, Poona, 1965.

Vyutpatti-Văda by Gadādhara Bhatțāaārya, with the commentary Jayā by Jayadeva Miśra, 3rd edn., Allahabad, 1953. [Footnote 33 refers to the Commentary Prakāsa on this text, published in Banaras. My copy does not indicate date of publication.]

\section{Critical Literature}

Cardona, George (1967-8): 'Anvaya and Vyatireka in Indian Grammar', Adyar Library Bulletin, 31-2, Madras, 1967-8.

Chatterjee, S. C. (1939): The Nyāya Theory of Knowledge, University of Calcutta, 1939, reprinted in 1965.

Chomsky, Noam (1964): 'Degrees of Grammaticalness', The Structure of Language, ed. by

Fodor and Katz, Prentice-Hall, New Jersey, 1964

Deshpande, Madhav (1972): 'Kauṇabhațta on the Philosophy of Nominal-Meaning', Nämärtha 
Nirnaya, text with tr. and notes, Ph.D. Dissertation, Dept. of Oriental Studies, University of Pennsylvania, Philadelphia, 1972.

Devasthali, G. V. (1959): Mīmāimsā: The Vākyaśästra of Ancient India, Bookseller's Publishing Company, Bombay, 1959.

Devasthali, G. V. (1974): Vàkya According to the Munitraya of Sanskrit Grammar, Charudeva Shastri Felicitation Volume, Delhi, 1974.

Jha, Ganganath (1933): English Translation of Säbara-Bhāsya, in three vols., Gaikwad's Oriental Series, Nos. 66, 70 and 73, Baroda, 1933, reprinted in 1973.

Joshi, S. D. (1968): Patañjali's Vyākarana-Mahābhāṣya, Samarthāhnika, ed. with tr. and nts., University of Poona, 1968.

Matilal, B. K. (1966): Indian Theorists on the Nature of the Sentence', Foundations of Language, II, 1966.

Mohanty, J. N. (1966): Gangesa's Theory of Truth, Centre of Advanced Study in Philosophy, Santiniketan, 1966.

Raja, Kunjunni K. (1963): Indian Theories of Meaning, The Adyar Library Series 91, Madras, 1963. 